\title{
Development of Indonesian Driving Anger Scale
}

\author{
Leksmono Suryo Putranto, Dwi Ch. Suryana, and Sunu Bagakara
}

\begin{abstract}
This paper is intended to develop Indonesian Driving Anger Scale by adopting several items of driving anger short scale developed by Deffenbacher et al in the USA. The respondents were asked to rate the amount of anger that would be provoked from none at all, a little, some, much and very much if the items in the questionnaire were actually happened. Respondents were 176 car drivers or motorcycle riders aged at least 17 years old and hold a valid driving license from Greater Jakarta. The proportion of respondents by gender was 116 males and 60 females. There were only 4 items trigger anger more than average (more than mean score 3.00), i.e. other driver yell at you rudely (3.90), someone weaving in and out of traffic (3.67), other driver drove very slowly in the fast lane and therefore slowing traffic (3.26) and someone backs right out in front of you without looking (3.68). Male respondents (2.85) were significantly $(\alpha=0.003)$ more hot-tempered than female respondents $(2.55)$ in terms of mean score of 14 items.
\end{abstract}

Index Terms - Driving anger scale, trigger anger, drivers yell.

\section{INTRODUCTION}

M otorization increase is rapidly in large cities in Indonesia. Therefore traffic accident is also increased. One of factors which possibly influence driving safety is anger.

Several studies explained the role of emotions and their effect to driving [1-5]. On their daily live, drivers experienced various types of emotions. Among various types of emotions, anger and fear were the most frequent happened [3]. Driving anger can cause various problems to the drivers [6]. On the other hand, fear was the most frequently happened to novice drivers [7-8].

Anger is a strong emotion related to aggressive and negative attitude towards the cause of anger and generally accompanied with muscle tension and stimulus of autonomous neural system [9]. Anger generally happened as a response to real threat, present behavioral disorder or as a response towards danger perception [10-11].

Parkinson [12] conducted a study using questionnaires to ask several items regarding anger frequency in driving and

L. S. Putranto is with the Department of Civil Engineering, University of Tarumanagara, 11440, West Jakarta, Indonesia (e-mail: lexy_putranto@yahoo.co.id).

D. C. Suryana is with the Department of Civil Engineering, University of Tarumanagara, 11440, West Jakarta, Indonesia.

S. Bagakara is with the Faculty of Psychology, University of YARSI, 10510, Central Jakarta, Indonesia. non-driving contexts. He concluded that emotion in the form of anger was more frequently happened in driving compared to non-driving contexts. Research conducted by [13] using diaries concluded that happiness $(54 \%)$ was the most frequent form of emotions during driving, followed by anger $(22 \%)$ and fear $(8 \%)$.

The consequence of emotion while driving such as speeding and accident involvement were also studied by several researchers. Arnett et al [14] conducted a study where they asked the participants to record their activities in 10 days. They found that anger was correlated with speeding, i.e. when the participants were angry, they tend to violate speed limit compared to non-angry situation. Underwood et al [13] also found that anger was related with accident or near-miss accident. Moreover, Deffenbacher et al [15] stated that in driving simulation, it was revealed that driver with high anger tend to drive in higher speed compared to non-angry driver.

Several researchers tried to explain why anger increased less-systematic processing style (in this case more heuristic). One possibility was based on affect-as-information approach [16], i.e. anger is basically an act as a signal of "take action now, think later!" This signal encouraged an individual to involve in a behavior which does not need deeper calculation. Anger is a "primitive emotion related with a relatively simple action (such as opposing) and consequently anger might probably trigger simple way of thinking (heuristic) rather than analytic. Likewise, anger might indicate dangerous or threatening environment. To be able to immediately save for such situation, a quick action is required. The need for quick action triggers heuristic processing approach. Therefore anger decreases motivation to involve in a controlled and systematic process.

Anger as an emotional response to certain situation is called as anger state and related to instant physiological and autonomous stimulus and muscle tension preparing the body to take action. This physical response will return to the baseline again after a specific situation overcome. On the other hand anger trait is related to general character of an individual to experience anger in various contexts and different situations. Individual with high anger trait has a general tendency to interpret surrounding events as threat to their ego and values. As a result, anger trait people with higher anger state will get angry more frequently than general populations [1].

Driving anger become a serious public problem because it may trigger driving behavior disorder [15, 17, 18]. Driving 
behavior disorder may contribute to road accident, causing serious injuries, fatalities and property damages [19-21]. According to [19], driving behavior disorder at least consists of three driving behaviors, i.e. aggressive driving, risky driving and driving error. These behaviors may threaten road safety.

Stephens and Groeger [22] studied whether emotions affect driving behavior in a simulator. There were 24 participants conducted simulated driving. During driving, they faced several traffic events designed to disturb their travel. Whilst in the simulator, participants were asked to rate their emotion. There were three types of emotions observed, i.e. frustration, calmness, and anger. The results show high anger and frustration and low calmness. Moreover, participants experienced anger, driving faster even in a dense traffic condition.

Garrity and Demick [23] studied relationship between driving performance and emotional state. In this research, they recruited an experienced observer to evaluate participant driving performance. The results show that emotional state was related to alertness. Participant with high depression, anger and fatigue scores was less alert compared to participant with low depression, anger and fatigue scores.

One mechanism that could explain causal relationship between anger to risky driving behavior is that an angry person does not think deeply about the future. These imply that angry person intension is far from the future and the consequences which may come [24]. There are several reasons behind this. Firstly, there were many problems in the past which may trigger an individual anger, especially events with violation of justice norms. Anger has deep "long impact" in a way that individual memory of events in the past often be able to trigger risky behavior. In this case, anger represents a kind of "primitive" emotion rooted to an individual memory on past events [25].

This paper is intended to develop Indonesian Driving Anger Scale by adopting driving anger scale developed by [26] in the USA. The full scale version [26] used 33 items classified into six subscales (hostile gestures, illegal driving, police presence, slow driving, and discourtesy and traffic obstructions. The short scale version consists of 14 items (the shortest possible scale that had adequate reliability and assessed the same sources of variance as the full scale). At first the authors decided to directly adopt the 14 items in the short scale version. However after conducting some discussions with local experts regarding the appropriateness of the items to reflect driving behavior in Indonesia, we exchanged four items in the short scale version with four items in the full scale version from the same cluster.

\section{Method}

The items in the full scale version of Driving Anger Scale [26], if grouped into six clusters were as follow (S indicates item in short scale version; I indicates selected item for Indonesian version):
TABLE I

DRIVING ANGER SCALE

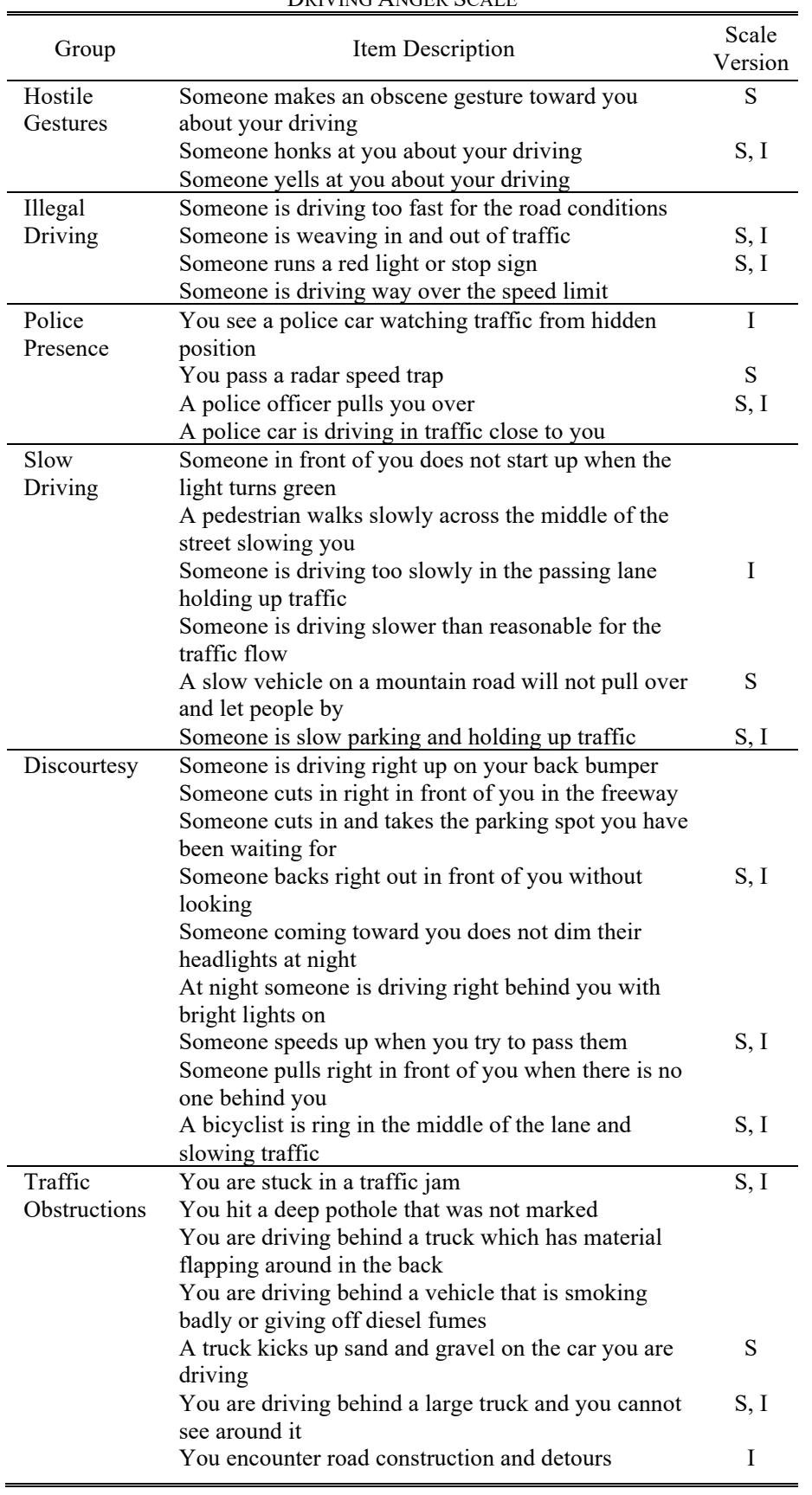

Respondents were 176 car drivers or motorcycle riders aged at least 17 years old and hold a valid driving license from Greater Jakarta. Altogether, there were 86 online respondents and 90 direct interview survey. The proportion of respondents by gender was 116 males and 60 females. Although there were 101 respondents who rode the motorcycle daily and 75 respondent who drove the car daily but there were 87 respondents who hold both motorcycle rider and car driver licenses. The remaining 89 respondents were either holding motorcycle rider or car driver licenses. Most of the respondents (170) were under 40 years old or fall within younger adult age group. $75 \%$ of the respondents were riding motorcycle or driving car more than 3 times a week. The respondents were asked to rate the amount of anger that would 
be provoked from none at all, a little, some, much and very much if the items in the questionnaire were actually happened. The respondents also asked to answer some general questions in the beginning, i.e. name, gender, age, type of vehicle used daily, type of possessed driving/ riding licenses, etc. Mean difference analysis was conducted with significant level of 0.05 between gender, age group, type of vehicle used daily, type of possessed licenses and frequency of weekly travel.

\section{ANALYSIS AND DISCUSSION}

Table II summarizes the overall data. It can be seen that There were only 4 items trigger anger more than average (more than mean score 3.00), i.e. other driver yell at you rudely (3.90), someone weaving in and out of traffic (3.67), other driver drove very slowly in the fast lane and therefore slowing traffic (3.26) and someone backs right out in front of you without looking (3.68). Yelling to the others is considered to be very hostile in Indonesian culture. Weaving in and out of traffic is considered to be very dangerous behavior. On the other hand the respondents did not mind to be pulled over by the police (1.78). This might reflect general attitude of the public towards the police (not necessarily respect them, but at least apprehend their law enforcement duties). Respondents also did not mind drive behind a large truck and were not able to see around it (1.92). Again this might reflect public apprehension to mobility difficulties of large trucks.

TABLE II

SUMMARY OF THE DATA

\begin{tabular}{clc}
\hline \hline No. & \multicolumn{1}{c}{ Item Description } & $\begin{array}{c}\text { Mean } \\
\text { Score }\end{array}$ \\
\hline 1. & Someone honks at you about your driving. & 2.02 \\
2. & Someone honks at you about your driving. & 3.90 \\
3. & Someone is weaving in and out of traffic. & 3.67 \\
4. & Someone runs a red light or stop sign. & 2.85 \\
5. & A police officer pulls you over. & 1.78 \\
6. & You see a police car watching traffic from hidden position. & 2.53 \\
7. & Someone is slow parking and holding up traffic. & 2.87 \\
8. & Someone is driving too slowly in the passing lane holding up & 3.26 \\
& traffic. & 3.68 \\
9. & Someone backs right out in front of you without looking. & 2.71 \\
10. & Someone speeds up when you try to pass them. & 2.77 \\
11. & A bicyclist is riding in the middle of the lane and slowing & \\
& traffic. & 2.47 \\
12. & You are stuck in a traffic jam. & 2.18 \\
13. & You encounter road construction and detours & 1.92 \\
14. & You are driving behind a large truck and you cannot see \\
& around it. & \\
\hline \hline
\end{tabular}

Table III shows mean difference of items scores between genders. It can be seen that for all statistically significant mean difference pairs, female mean scores were lower than male mean scores. There were seven pairs with statistical significant difference, i.e.: someone runs a red light or stop sign, a police officer pulls you over, you see a police car watching traffic from hidden position, someone speeds up when you try to pass them, a bicyclist is riding in the middle of the lane and slowing traffic, you are stuck in a traffic jam and you encounter road construction and detours. These imply that for those seven items, female respondents were less angry compared to male respondents. It might be due to the characteristics of the item which were not related to sensitive female feelings. Hostile gestures seem to affect more anger to female respondents although in two items reflecting hostile gestures the mean differences were not statistically significant. In terms of overall mean, the instrument affect less anger to female respondents (2.55) compared to male respondents (2.86). This pair was statistically significant $(0.003)$.

TABLE III

MEAN DifFERENCE Of ITEMS SCORES BETWEEN GENDER

\begin{tabular}{|c|c|c|c|c|c|c|}
\hline \multirow[b]{2}{*}{ No. } & \multirow[b]{2}{*}{ Item Description } & \multicolumn{3}{|c|}{ Mean Score } & \multirow[b]{2}{*}{$\alpha$} & \multirow{2}{*}{$\begin{array}{c}\text { Signi } \\
\text { ficant } \\
\text { (Yes/No?) }\end{array}$} \\
\hline & & $\begin{array}{c}\text { Male } \\
\mathrm{N}=116\end{array}$ & $\begin{array}{l}\text { Female } \\
\mathrm{N}=60\end{array}$ & $\begin{array}{l}\text { Diffe } \\
\text { rence }\end{array}$ & & \\
\hline 1. & $\begin{array}{l}\text { Someone honks at you } \\
\text { about your driving. }\end{array}$ & 1.97 & 2.10 & -0.13 & 0.459 & No \\
\hline 2. & $\begin{array}{l}\text { Someone honks at you } \\
\text { about your driving. }\end{array}$ & 3.89 & 3.93 & -0.04 & 0.806 & No \\
\hline 3. & $\begin{array}{l}\text { Someone is weaving in } \\
\text { and out of traffic. }\end{array}$ & 3.66 & 3.67 & -0.01 & 0.988 & No \\
\hline 4. & $\begin{array}{l}\text { Someone runs a red } \\
\text { light or stop sign. }\end{array}$ & 3.09 & 2.40 & 0.69 & 0.002 & Yes \\
\hline 5. & $\begin{array}{l}\text { A police officer pulls } \\
\text { you over. }\end{array}$ & 1.91 & 1.53 & 0.38 & 0.014 & Yes \\
\hline 6. & $\begin{array}{l}\text { You see a police car } \\
\text { watching traffic from } \\
\text { hidden position. }\end{array}$ & 2.78 & 2.05 & 0.73 & 0.001 & Yes \\
\hline 7. & $\begin{array}{l}\text { Someone is slow } \\
\text { parking and holding up } \\
\text { traffic. }\end{array}$ & 3.00 & 2.63 & 0.37 & 0.068 & No \\
\hline 8. & $\begin{array}{l}\text { Someone is driving too } \\
\text { slowly in the passing } \\
\text { lane holding up traffic. }\end{array}$ & 3.33 & 3.12 & 0.21 & 0.277 & No \\
\hline 9. & $\begin{array}{l}\text { Someone backs right } \\
\text { out in front of you } \\
\text { without looking. }\end{array}$ & 3.71 & 3.62 & 0.09 & 0.622 & No \\
\hline 10. & $\begin{array}{l}\text { Someone speeds up } \\
\text { when you try to pass } \\
\text { them. }\end{array}$ & 2.84 & 2.43 & 0.41 & 0.043 & Yes \\
\hline 11. & $\begin{array}{l}\text { A bicyclist is riding in } \\
\text { the middle of the lane } \\
\text { and slowing traffic. }\end{array}$ & 2.90 & 2.52 & 0.38 & 0.048 & Yes \\
\hline 12. & $\begin{array}{l}\text { You are stuck in a } \\
\text { traffic jam. }\end{array}$ & 2.63 & 2.15 & 0.48 & 0.009 & Yes \\
\hline 13. & $\begin{array}{l}\text { You encounter road } \\
\text { construction and } \\
\text { detours }\end{array}$ & 2.39 & 1.78 & 0.61 & 0.001 & Yes \\
\hline 14. & $\begin{array}{l}\text { You are driving behind } \\
\text { a large truck and you } \\
\text { cannot see around it. }\end{array}$ & 1.98 & 1.80 & 0.18 & 0.272 & No \\
\hline & Mean & 2.86 & 2.55 & 0.31 & 0.003 & Yes \\
\hline
\end{tabular}

Tables IV through 6 show that in general there were no statistically difference in the 14 items between age group, type of vehicle, type of possessed license and frequency of weekly travel. The only pair with statistically significant mean difference was overall mean of vehicle type (Table V). Surprisingly motorcycle riders responded less anger to overall items of the instrument compared to car drivers. This might be due the nature of the original questionnaires [26] which was prepared for car drivers. Interesting results of statistically significant mean difference of overall mean between gender (0.31) and between vehicle type (0.067). Those quite marginal difference values can be statistically significant due to lower variance of overall mean compared to individual items means. 
In the vehicle type case, it was even more dramatic because overall mean difference was statistically significant although none of mean difference of individual items were statistically significant.

TABLE IV

MEAN DIFFERENCE OF ITEMS SCORES BETWEEN AGE GROUP

\begin{tabular}{|c|c|c|c|c|c|c|}
\hline \multirow[b]{2}{*}{ No. } & \multirow[b]{2}{*}{ Item Description } & \multicolumn{3}{|c|}{ Mean Score } & \multirow[b]{2}{*}{$\alpha$} & \multirow{2}{*}{$\begin{array}{c}\text { Signi } \\
\text { ficant } \\
\text { (Yes/No?) }\end{array}$} \\
\hline & & $\begin{array}{l}\geq 40 \\
\text { years } \\
\mathrm{N}=6\end{array}$ & $\begin{array}{c}<40 \\
\text { years } \\
\mathrm{N}=170\end{array}$ & $\begin{array}{l}\text { Diffe } \\
\text { rence }\end{array}$ & & \\
\hline 1. & $\begin{array}{l}\text { Someone honks at you } \\
\text { about your driving. }\end{array}$ & 2.83 & 1.99 & 0.84 & 0.056 & No \\
\hline 2. & $\begin{array}{l}\text { Someone honks at you } \\
\text { about your driving. }\end{array}$ & 3.67 & 3.91 & -0.24 & 0.611 & No \\
\hline 3. & $\begin{array}{l}\text { Someone is weaving in } \\
\text { and out of traffic. }\end{array}$ & 3.50 & 3.67 & -0.17 & 0.733 & No \\
\hline 4. & $\begin{array}{l}\text { Someone runs a red } \\
\text { light or stop sign. }\end{array}$ & 3.33 & 2.84 & 0.50 & 0.406 & No \\
\hline 5. & $\begin{array}{l}\text { A police officer pulls } \\
\text { you over. }\end{array}$ & 1.83 & 1.78 & 0.06 & 0.899 & No \\
\hline 6. & $\begin{array}{l}\text { You see a police car } \\
\text { watching traffic from } \\
\text { hidden position. }\end{array}$ & 2.67 & 2.52 & 1.43 & 0.813 & No \\
\hline 7. & $\begin{array}{l}\text { Someone is slow } \\
\text { parking and holding up } \\
\text { traffic. }\end{array}$ & 3.00 & 2.87 & 0.13 & 0.655 & No \\
\hline 8. & $\begin{array}{l}\text { Someone is driving too } \\
\text { slowly in the passing } \\
\text { lane holding up traffic. }\end{array}$ & 3.33 & 3.25 & 0.08 & 0.874 & No \\
\hline 9. & $\begin{array}{l}\text { Someone backs right } \\
\text { out in front of you } \\
\text { without looking. }\end{array}$ & 3.17 & 3.69 & -0.53 & 0.270 & No \\
\hline 10. & $\begin{array}{l}\text { Someone speeds up } \\
\text { when you try to pass } \\
\text { them. }\end{array}$ & 3.33 & 2.68 & 0.65 & 0.222 & No \\
\hline 11. & $\begin{array}{l}\text { A bicyclist is riding in } \\
\text { the middle of the lane } \\
\text { and slowing traffic. }\end{array}$ & 2.83 & 2.76 & 0.07 & 0.892 & No \\
\hline 12. & $\begin{array}{l}\text { You are stuck in a } \\
\text { traffic jam. }\end{array}$ & 2.00 & 2.48 & -0.48 & 0.367 & No \\
\hline 13. & $\begin{array}{l}\text { You encounter road } \\
\text { construction and } \\
\text { detours }\end{array}$ & 1.83 & 2.19 & -0.36 & 0.484 & No \\
\hline 14. & $\begin{array}{l}\text { You are driving behind } \\
\text { a large truck and you } \\
\text { cannot see around it. }\end{array}$ & 2.17 & 1.91 & 0.25 & 0.558 & No \\
\hline & Mean & 2.82 & 2.75 & 0.067 & 0.827 & No \\
\hline
\end{tabular}

Both overall (14 items) mean value of he result in Table III (gender group) and Table IV (vehicle type group) were still less than 3.00 (the departure between low anger to high anger). However, if a priority should be taken regarding socialization of anger control, the above results imply that male and car driver groups should be prioritized.

TABLE V

MEAN DIFFERENCE OF ITEMS SCORES BETWEEN TYPE OF VEHICLE

\begin{tabular}{|c|c|c|c|c|c|c|}
\hline \multirow[b]{2}{*}{ No. } & \multirow[b]{2}{*}{ Item Description } & \multicolumn{3}{|c|}{ Mean Score } & \multirow[b]{2}{*}{$\alpha$} & \multirow[b]{2}{*}{$\begin{array}{c}\text { Signi } \\
\text { ficant } \\
\text { (Yes/No? }\end{array}$} \\
\hline & & $\begin{array}{l}\text { Motor- } \\
\text { cycle } \\
\mathrm{N}=101\end{array}$ & $\begin{array}{c}\mathrm{Car} \\
\mathrm{N}=75\end{array}$ & $\begin{array}{l}\text { Diffe } \\
\text { rence }\end{array}$ & & \\
\hline 1. & $\begin{array}{l}\text { Someone honks at you } \\
\text { about your driving. }\end{array}$ & 1.78 & 2.33 & -0.55 & 0.001 & Yes \\
\hline 2. & $\begin{array}{l}\text { Someone honks at you } \\
\text { about your driving. }\end{array}$ & 3.81 & 4.03 & -0.22 & 0.223 & No \\
\hline 3. & $\begin{array}{l}\text { Someone is weaving in } \\
\text { and out of traffic. }\end{array}$ & 3.59 & 3.76 & -0.17 & 0.365 & No \\
\hline
\end{tabular}

\begin{tabular}{|c|c|c|c|c|c|c|}
\hline \multirow[b]{2}{*}{ No. } & \multirow[b]{2}{*}{ Item Description } & \multicolumn{3}{|c|}{ Mean Score } & \multirow[b]{2}{*}{$\alpha$} & \multirow[b]{2}{*}{$\begin{array}{r}\text { Signi } \\
\text { ficant } \\
\text { (Yes/No?) }\end{array}$} \\
\hline & & $\begin{array}{c}\text { Motor- } \\
\text { cycle } \\
\mathrm{N}=101\end{array}$ & $\begin{array}{c}\text { Car } \\
\mathrm{N}=75\end{array}$ & $\begin{array}{l}\text { Diffe } \\
\text { rence }\end{array}$ & & \\
\hline 4. & $\begin{array}{l}\text { Someone runs a red } \\
\text { light or stop sign. }\end{array}$ & 2.67 & 3.09 & -0.42 & 0.055 & No \\
\hline 5. & $\begin{array}{l}\text { A police officer pulls } \\
\text { you over. }\end{array}$ & 1.65 & 1.95 & -0.30 & 0.072 & No \\
\hline 6. & $\begin{array}{l}\text { You see a police car } \\
\text { watching traffic from } \\
\text { hidden position. }\end{array}$ & 2.45 & 2.64 & -0.19 & 0.382 & No \\
\hline 7. & $\begin{array}{l}\text { Someone is slow } \\
\text { parking and holding up } \\
\text { traffic. }\end{array}$ & 2.73 & 3.07 & -0.34 & 0.083 & No \\
\hline 8. & $\begin{array}{l}\text { Someone is driving too } \\
\text { slowly in the passing } \\
\text { lane holding up traffic. }\end{array}$ & 3.11 & 3.45 & -0.34 & 0.063 & No \\
\hline 9. & $\begin{array}{l}\text { Someone backs right } \\
\text { out in front of you } \\
\text { without looking. }\end{array}$ & 3.55 & 3.84 & -0.29 & 0.103 & No \\
\hline 10. & $\begin{array}{l}\text { Someone speeds up } \\
\text { when you try to pass } \\
\text { them. }\end{array}$ & 2.65 & 2.77 & -0.12 & 0.540 & No \\
\hline 11. & $\begin{array}{l}\text { A bicyclist is riding in } \\
\text { the middle of the lane } \\
\text { and slowing traffic. }\end{array}$ & 2.65 & 2.92 & -0.27 & 0.148 & No \\
\hline 12. & $\begin{array}{l}\text { You are stuck in a } \\
\text { traffic jam. }\end{array}$ & 2.47 & 2.47 & 0.00 & 0.995 & No \\
\hline 13. & $\begin{array}{l}\text { You encounter road } \\
\text { construction and } \\
\text { detours }\end{array}$ & 2.11 & 2.28 & -0.17 & 0.366 & No \\
\hline 14. & $\begin{array}{l}\text { You are driving behind } \\
\text { a large truck and you } \\
\text { cannot see around it. }\end{array}$ & 1.91 & 1.93 & -0.02 & 0.892 & No \\
\hline & Mean & 2.65 & 2.89 & -0.24 & 0.031 & Yes \\
\hline
\end{tabular}

TABLE VI

MEAN DIFFERENCE OF ITEMS SCORES BETWEEN TYPE OF POSSESSED LICENSE

\begin{tabular}{|c|c|c|c|c|c|c|}
\hline \multirow[b]{2}{*}{ No. } & \multirow[b]{2}{*}{ Item Description } & \multicolumn{3}{|c|}{ Mean Score } & \multirow[b]{2}{*}{$\alpha$} & \multirow{2}{*}{$\begin{array}{c}\text { Signi } \\
\text { ficant } \\
\text { (Yes/No? }\end{array}$} \\
\hline & & $\begin{array}{l}A \& C \\
N=87\end{array}$ & $\begin{array}{c}\mathrm{A} / \mathrm{C} \\
\mathrm{N}=89\end{array}$ & $\begin{array}{l}\text { Diffe } \\
\text { rence }\end{array}$ & & \\
\hline 1. & $\begin{array}{l}\text { Someone honks at you } \\
\text { about your driving. }\end{array}$ & 1.98 & 2.06 & -0.08 & 0.624 & No \\
\hline 2. & $\begin{array}{l}\text { Someone honks at you } \\
\text { about your driving. }\end{array}$ & 3.90 & 3.91 & -0.01 & 0.938 & No \\
\hline 3. & $\begin{array}{l}\text { Someone is weaving in } \\
\text { and out of traffic. }\end{array}$ & 3.70 & 3.63 & 0.07 & 0.692 & No \\
\hline 4. & $\begin{array}{l}\text { Someone runs a red } \\
\text { light or stop sign. }\end{array}$ & 2.87 & 2.83 & 0.04 & 0.847 & No \\
\hline 5. & $\begin{array}{l}\text { A police officer pulls } \\
\text { you over. }\end{array}$ & 1.85 & 1.71 & 0.14 & 0.378 & No \\
\hline 6. & $\begin{array}{l}\text { You see a police car } \\
\text { watching traffic from } \\
\text { hidden position. }\end{array}$ & 2.68 & 2.38 & 0.30 & 0.178 & No \\
\hline 7. & $\begin{array}{l}\text { Someone is slow } \\
\text { parking and holding up } \\
\text { traffic. }\end{array}$ & 3.00 & 2.75 & 0.25 & 0.195 & No \\
\hline 8. & $\begin{array}{l}\text { Someone is driving too } \\
\text { slowly in the passing } \\
\text { lane holding up traffic. }\end{array}$ & 3.31 & 3.20 & 0.11 & 0.557 & No \\
\hline 9. & $\begin{array}{l}\text { Someone backs right } \\
\text { out in front of you } \\
\text { without looking. }\end{array}$ & 3.64 & 3.71 & -0.07 & 0.712 & No \\
\hline 10. & $\begin{array}{l}\text { Someone speeds up } \\
\text { when you try to pass } \\
\text { them. }\end{array}$ & 3.63 & 2.78 & -0.15 & 0.460 & No \\
\hline 11. & $\begin{array}{l}\text { A bicyclist is riding in } \\
\text { the middle of the lane } \\
\text { and slowing traffic. }\end{array}$ & 2.84 & 2.70 & 0.14 & 0.436 & No \\
\hline 12. & $\begin{array}{l}\text { You are stuck in a } \\
\text { traffic jam. }\end{array}$ & 2.41 & 3.52 & -0.11 & 0.595 & No \\
\hline
\end{tabular}




\begin{tabular}{ccccccc}
\hline \hline & & \multicolumn{3}{c}{ Mean Score } & & $\begin{array}{c}\text { Signi } \\
\text { No. }\end{array}$ \\
\cline { 3 - 5 } & Item Description & $\begin{array}{c}\mathrm{A} \& \mathrm{C} \\
\mathrm{N}=87\end{array}$ & $\begin{array}{c}\mathrm{A} / \mathrm{C} \\
\mathrm{N}=89\end{array}$ & $\begin{array}{c}\text { Diffe } \\
\text { rence }\end{array}$ & & $\begin{array}{c}\text { ficant } \\
\text { (Yes/No?) }\end{array}$ \\
\hline 13. & $\begin{array}{l}\text { You encounter road } \\
\text { construction and } \\
\text { detours }\end{array}$ & 2.20 & 2.17 & 0.03 & 0.886 & No \\
$\begin{array}{l}\text { You are driving behind } \\
\text { a large truck and you } \\
\text { cannot see around it. }\end{array}$ & 1.86 & 1.98 & -0.12 & 0.465 & No \\
\hline Mean & 2.78 & 2.74 & 0.04 & 0.721 & No \\
\hline \hline
\end{tabular}

TABLE VII

MEAN DIFFERENCE OF ITEMS SCORES BETWEEN WEEKLY TRAVEL FREQUENCY USING PRIVATE VEHICLE

\begin{tabular}{|c|c|c|c|c|c|c|}
\hline \multirow[b]{2}{*}{ No. } & \multirow[b]{2}{*}{ Item Description } & \multicolumn{3}{|c|}{ Mean Score } & \multirow[b]{2}{*}{$\alpha$} & \multirow[b]{2}{*}{$\begin{array}{c}\text { Signi } \\
\text { ficant } \\
\text { (Yes/No?) }\end{array}$} \\
\hline & & $\begin{array}{l}\leq 3 \\
\text { times } \\
\mathrm{N}=44\end{array}$ & $\begin{array}{c}>3 \\
\text { times } \\
\mathrm{N}=132\end{array}$ & $\begin{array}{l}\text { Diffe } \\
\text { rence }\end{array}$ & & \\
\hline 1. & $\begin{array}{l}\text { Someone honks at you } \\
\text { about your driving. }\end{array}$ & 2.07 & 2.00 & 0.07 & 0.714 & No \\
\hline 2. & $\begin{array}{l}\text { Someone honks at you } \\
\text { about your driving. }\end{array}$ & 3.82 & 3.93 & -0.11 & 0.573 & No \\
\hline 3. & $\begin{array}{l}\text { Someone is weaving in } \\
\text { and out of traffic. }\end{array}$ & 3.66 & 3.67 & -0.01 & 0.969 & No \\
\hline 4. & $\begin{array}{l}\text { Someone runs a red } \\
\text { light or stop sign. }\end{array}$ & 2.89 & 2.84 & 0.05 & 0.844 & No \\
\hline 5. & $\begin{array}{l}\text { A police officer pulls } \\
\text { you over. }\end{array}$ & 1.66 & 1.82 & -0.16 & 0.395 & No \\
\hline 6. & $\begin{array}{l}\text { You see a police car } \\
\text { watching traffic from } \\
\text { hidden position. }\end{array}$ & 2.52 & 2.53 & -0.01 & 0.976 & No \\
\hline 7. & $\begin{array}{l}\text { Someone is slow } \\
\text { parking and holding up } \\
\text { traffic. }\end{array}$ & 2.89 & 2.87 & 0.02 & 0.939 & No \\
\hline 8. & $\begin{array}{l}\text { Someone is driving too } \\
\text { slowly in the passing } \\
\text { lane holding up traffic. }\end{array}$ & 3.14 & 3.30 & -0.16 & 0.423 & No \\
\hline 9. & $\begin{array}{l}\text { Someone backs right } \\
\text { out in front of you } \\
\text { without looking. }\end{array}$ & 3.59 & 3.70 & -0.11 & 0.571 & No \\
\hline 10. & $\begin{array}{l}\text { Someone speeds up } \\
\text { when you try to pass } \\
\text { them. }\end{array}$ & 2.80 & 2.67 & 0.13 & 0.588 & No \\
\hline 11. & $\begin{array}{l}\text { A bicyclist is riding in } \\
\text { the middle of the lane } \\
\text { and slowing traffic. }\end{array}$ & 2.80 & 2.76 & 0.04 & 0.844 & No \\
\hline 12. & $\begin{array}{l}\text { You are stuck in a } \\
\text { traffic jam. }\end{array}$ & 2.61 & 2,42 & 0.19 & 0.380 & No \\
\hline 13. & $\begin{array}{l}\text { You encounter road } \\
\text { construction and } \\
\text { detours }\end{array}$ & 2.05 & 2.23 & -0.18 & 0.400 & No \\
\hline 14. & $\begin{array}{l}\text { You are driving behind } \\
\text { a large truck and you } \\
\text { cannot see around it. }\end{array}$ & 2.07 & 1.87 & 0.20 & 0.280 & No \\
\hline & Mean & 2.75 & 2.76 & -0.01 & 0.973 & No \\
\hline
\end{tabular}

\section{CONCLUSIONS AND RECOMMENDATION}

From this paper, it can be concluded that:

1. The Indonesian Driver Anger Scale in this paper was mostly using the short scale version of [26]. However some items were replaced with items from the full scale version of [26] to maintain relevance with Indonesian drivers/ riders behaviour context.

2. The level of anger of the respondents was relatively low. There were only four out of fourteen items in the instrument which had mean score above three (the departure value from not angry to angry).

3. When the respondents face real driving/ riding situations listed in the instrument, female respondent was less angry compared to the male respondents.

4. In the vehicle type case, the overall mean difference was statistically significant although none of mean difference of individual items were statistically significant. This might be due the nature of the original questionnaires [26] which was prepared for car drivers.

It is recommended to test the Indonesian Driver Anger Scale to more respondents with more diverse driving culture and condition from different parts of Indonesia.

\section{REFERENCES}

[1] J.L. Deffenbacher, R.S. Lynch, E.R. Oetting, and D.A. Yingling, "Driving anger: Correlates and a test of state-trait theory," Personality and Individual Differences, 31(8), 1321-1331, 2001.

[2] T.-Y. Hu, X. Xie, and J. Li, "Negative or positive? The effect of emotion and mood on risky driving," Transportation Research Part F: Traffic Psychology and Behaviour, 16, 29-40, 2013.

[3] J. Mesken, M.P. Hagenzieker, T. Rothengatter, and D. de Waard, "Frequency, determinants, and consequences of different drivers' emotions: An on-the-road study using self-reports,(observed) behaviour, and physiology," Transportation Research Part F: Traffic Psychology and Behaviour, 10(6), 458-475, 2007.

[4] N. Rhodes, and K. Pivik, "Age and gender differences in risky driving: The roles of positive affect and risk perception," Accident Analysis \& Prevention, 43(3), 923-931, 2011.

[5] O. Taubman-Ben-Ari, "The effects of positive emotion priming on selfreported reckless driving," Accident Analysis \& Prevention, 45, 718725,2012

[6] C.S. Dula, and E.S. Geller, "Risky, aggressive, or emotional driving: Addressing the need for consistent communication in research," Journal of Safety Research, 34(5), 559-566, 2003.

[7] J.E. Taylor, F.P. Deane, and J.V. Podd, "Driving-related fear: A review," Clinical Psychology Review, 22(5), 631-645, 2002.

[8] J. E. Taylor, F. P. Deane, and J. V. Podd, "Driving fear and driving skills: Comparison between fearful and control samples using standardised on-road assessment," Behaviour Research \& Therapy, 45(4), 805-818 (2007).

[9] R.K. Hambleton, P.F. Merenda, and C.D. Spielberger, Adapting educational \& psychological tests for cross-cultural assessment. Psychology Press, New York, 2004.

[10] J.R. Averill, "Studies on anger and aggression: implications for theories of emotion," American Psychologist, 38(11), 1145-1160, 1983.

[11] A.M. Kring, "Gender and anger," in A. H. Fischer (Ed.), Gender \& emotion: Social psychological perspectives. Cambridge, 2000.

[12] B. Parkinson, "Anger on and off the road," British Journal of Psychology, 92(3), 507-526, 2001.

[13] G. Underwood, P. Chapman, S. Wright, and D. Crundall, "Anger while driving," Transportation Research Part F: Traffic Psychology and Behaviour, 2(1), 55-68, 1999.

[14] J.J. Arnett, D. Offer, and M.A. Fine, "Reckless driving in adolescence: 'State' and 'trait' factors," Accident Analysis \& Prevention, 29(1), 5763, 1997.

[15] J.L.,Deffenbacher, R.S. Lynch,D.M. Deffenbacher, and E.R. Oetting, "Further evidence of reliability and validity for the Driving Anger Expression Inventory," Psychological Reports, 89(3), 535-540, 2001.

[16] N. Schwarz, Feelings as information: Informational and motivational functions of affective states. New York, 1990.

[17] E.R. Dahlen, R.C. Martin, K. Ragan, K., and M.M. Kuhlman, "Driving anger, sensation seeking, impulsiveness, and boredom proneness in the prediction of unsafe driving," Accident Analysis \& Prevention, 37(2), 341-348, 2005. 
[18] T. Lajunen, D. Parker, and S.G. Stradling, "Dimensions of driver anger, aggressive and highway code violations and their mediation by safety orientation in UK drivers," Transportation Research Part F: Traffic Psychology and Behaviour, 1(2), 107-121, 1998.

[19] J.C. de Winter, and D. Dodou, "The Driver Behaviour Questionnaire as a predictor of accidents: A meta-analysis," Journal of Safety Research, 41(6), 463-470, 2010.

[20] H. Iversen, and T. Rundmo, "Attitudes towards traffic safety, driving behaviour and accident involvement among the Norwegian public," Ergonomics, 47(5), 555-572, 2004.

[21] R. Paleti, N. Eluru, N., and C.R. Bhat, "Examining the influence of aggressive driving behavior on driver injury severity in traffic crashes," Accident Analysis \& Prevention, 42(6), 1839-1854, 2010.

[22] A.N. Stephens, and J.A. Groeger, "Do emotional appraisals of traffic situations influence driver behaviour?" in Behavioural Research in Road Safety Sixteenth Seminar, 2006.

[23] R.D. Garrity, and J. Demick, "Relations among personality traits, mood states, and driving behaviors," Journal of Adult Development, 8(2), 109118,2001

[24] Wenstein, E.U. Weber, C.K. Hsee, and N. Welch, "Risk as feelings," Psychological Bulletin, 127(2), 267-286 (2001).

[25] K.B. Starzyk, C.W. Blatz, and Ross, M., "Acknowledging and redressing historical injustice," in J.T. Jost, A.C. Kay, and H. Thorisdottir, Social and psychological bases of ideology and system justification. Oxford University Press, 2009.

[26] J.L. Deffenbacher, E.R. Oetting, and R.S. Lynch, " Development of a driving anger scale," Psychological Reports, 74(1), 83-91, 1994. 